\title{
EVALUASI IMPLEMENTASI PRINSIP EKOWISATA BERBASIS MASYARAKAT DALAM PENGELOLAAN CLUNGUP MANGROVE CONSERVATION SUMBERMANJING WETAN, MALANG
}

\section{Evaluation of the Implementation of Community-Based Ecotourism Principles in Management of Clungup Mangrove Conservation, Sumbermanjing Wetan, Malang}

\author{
Husamah $^{\mathrm{a}}$, Atok Miftachul Hudha ${ }^{\mathrm{b}}$ \\ ${ }^{a}$ Pusat Studi Lingkungan dan Kependudukan (PSLK) dan Program Studi Pendidikan Biologi-FKIP, Universitas \\ Muhammadiyah Malang, Kampus III UMM, Malang65144-usya_bio@yahoo.com \\ ${ }^{b}$ Pusat Studi Lingkungan dan Kependudukan (PSLK), Universitas Muhammadiyah Malang, Kampus III UMM, \\ Malang 65144
}

\begin{abstract}
Clungup Mangrove Conservation (CMC) is a new ecotourism destination managed by a community group called 'Bhakti Alam Sendang Biru'. This study aimed to analyze the implementation of the 5 principles of Community-based Ecotourism in the management of CMC, namely: (1) Conservation principle (Nature conservation principle, 6 criterias and culture conservation, 4 criterias), (2) Community participation principle (7 criterias), (3) Economic principle (5 criterias), (4) Education principle (5 criterias), and (5) Tourism principle (6 criterias). This research method is descriptive qualitative. Source of the data obtained are primary data obtained through observation to the site to conduct an interview to the informants and secondary data obtained through the study of literature and documents. The data obtained were processed with descriptive techniques. The results showed that in general the 5 principles of community-based ecotourism have been implemented in the management of CMC although some criteria for each principle there is not yet implemented, is being planned, pursued, and optimized.
\end{abstract}

Keywords: CMC, community-based ecotourism, conservation, mangrove, participation

(Diterima: 18-03-2017; Disetujui: 12-10-2017)

\section{Pendahuluan}

Salah satu bagian terpenting dari kondisi geografis Indonesia sebagai wilayah kepulauan yaitu wilayah pantai dan pesisir dengan garis pantai sepanjang 81.000 k(Koddeng, 2011; Lasabuda, 2013). Wilayah pantai dan pesisir memiliki arti strategis karena merupakan wilayah interaksi/peralihan (interface) antara ekosistem darat dan ekosistem laut yang memiliki sifat dan ciri yang unik, dan mengandung produksi biologi cukup besar serta jasa lingkungan lainnya (Sodikin, 2012). Kekayaan sumber daya yang dimiliki menimbulkan daya tarik bagi beberapa pihak untuk memanfaatkan secara langsung (Subekti, 2012; Yulius \& Arifin, 2014) atau mengelola berdasarkan peraturan yang berlaku (Tambunan et al., 2009; Astra et al., 2014) dan sesuai semangat berkelanjutan misalnya mengelola kegiatan wisata dengan tetap melakukan pemeliharaan sumberdaya alamdan konservasi (Ekayani et al., 2014a). Secara sektoral wilayah pantai memberikan sumbangan yang besar dalam kegiatan ekonomi misalnya pertambangan, perikanan, kehutanan, industri, pariwisata dan lain-lain (Riyadi, 2004; Sodikin, 2012). Wilayah pesisir merupakan ekosistem transisi yang dipengaruhi daratan dan lautan, yang mencakup beberapa ekosistem, salah satunya adalah ekosistem hutan mangrove (Huda \& Susetyo, 2013).

Clungup Mangrove Conservation (CMC) adalah destinasi ekowisata baru dan tengah menjadi primadona di Kabupaten Malang (Mubariza, 2015; Hakim,
2016). Keindahan dan daya tarik CMC juga diakui oleh Pemerintah Provinsi Jawa Timur (Kominfo Jatim, 2016) dan situs tempat wisata indonesia.id (Anonim, 2016).Ekowisata ini dikelola oleh kelompok masyarakat bernama 'Bhakti Alam Sendang Biru', dikoordinasi oleh Bapak Saptoyo yang bertujuan untuk menyelamatkan ekosistem mangrove dan pantai/pesisir (termasuk terumbu karang), berdiri sejak 2012. Area mangrove yang dikelola telah mencapai luas 81 hektar dan sempadan pantai seluas 117 hektar. CMC mengelola 3 pantai utama, yaitu Pantai Clungup, Pantai Gatra, dan Pantai Tiga Warna (Anggawa, 2016).

Kelompok atau Lembaga Masyarakat Konservasi Bhakti Alam Sendang Birusecara konsisten melakukan kegiatan konservasi kawasan mangrove pesisir pantai dan mengelola kawasan tersebut untuk tujuan wisata terbatas. Model pengelolaan CMC tetap mempertimbangkan prinsip ekologis wilayah atau dikenal dengan ecotourism (ekowisata). Pemanfaatan lahan konservasi ini didasarkan pada asas manfaat ekonomi dan pemberdayaan masyarakat lokal sekitar area konservasi (Anonim, 2015). Pengelolaan ekowisata CMC oleh Lembaga Masyarakat Konservasi Bhakti Alam Sendang Biru telah mendapatkan apresiasi dan pengakuan dari berbagai pihak. Ekowisata CMC pada tanggal 11 Desember 2015 menjadi juara satu kompetisi nasional Adi Bakti Mina Bahari 2015 Kementrian Kelautan dan Perikanan, bidang kelautan, pesisir, dan pulau-pulau kecil, kategori Pengembangan Kawasan Pesisir Tangguh (Pamuji, 2015).

doi: $10.29244 /$ jpsl.8.1.86-95 
CMC merupakan wujud ekowisata berbasis masyarakat yang baik menurut Kementrian Kelautan dan Perikanan, meskipun pengelolaannya baru dilakukan sejak 2012 (baru berumur 4 tahun). Menurut Haerani (2012) ekowisata merupakan kegiatan pariwisata atau wisata terbatas yang memanfaatkan tatanan, nilai, dan fungsi ekologi sebagai obyek dan tujuan kepariwisataan. Sementara itu, menurut TIES (2015) ekowisata saat ini didefinisikan sebagai perjalanan yang bertanggung jawab ke daerah-daerah alami yang melestarikan lingkungan, menopang kesejahteraan masyarakat setempat, dan melibatkan interpretasi dan pendidikan.

Ekowisata merupakan suatu konsep pengembangan pariwisata berkelanjutan yang bertujuan untuk mendukung upaya-upaya pelestarian lingkungan (alam dan budaya) dan meningkatkan partisipasi masyarakat dalam pengelolaan sehingga memberi manfaat ekonomi kepada masyarakat setempat. Ekowisata adalah salah satu mekanisme pembangunan yang berkelanjutan (sustainable development) (Priono, 2012). Ekowisata merupakan pariwisata alternatif yang timbul sebagai konsekuensi dari ketidakpuasan terhadap bentuk pariwisata yang kurang memperhatikan dampak sosial dan ekologis, dan lebih mementingkan keuntungan ekonomi dan kenyamanan manusia semata (Nugraheni, 2002; El Sahawi, 2015).

Ekowisata merupakan aktivitas potensial yang dapat dipertimbangkan sebagai suatu pilihan untuk ekonomi lokal (ILO, 2012). Kenyataannya adalah usaha-usaha pengembangan pariwisata yang berorientasi pada masyarakat lokal masih minim dan banyak mengalami kegagalan. Hal ini karena para pemegang kebijakan masih berpikir parsial, ego istitusi, dan ego sektoral (Singgih \& Nirwana, 2016). Mereka menganggap masyarakat tidak memiliki kemampuan secara finansial dan keahlian yang berkualitas untuk mengelola atau terlibat langsung dalam kegiatan pariwisata yang berbasiskan alam dan budaya. Pariwisata berbasis masyarakat memerlukan partisipasi aktif untuk menjadi tuan rumah yang baik, menyediakan sesuatu yang terbaik sesuai kemampuan, ikut menjaga keamanan, ketentraman, keindahan dan kebersihan lingkungan, memberikan kenangan dan kesan yang baik bagi wisatawan (Soetomo, 2007).

Ekowisata yang melibatkan masyarakat secara konsisten akandapat memberikan manfaat/dampak ekonomi bagi masyarakat dan manfaat bagi konservasi/kelestarian.Pendapat tersebut dapat dibuktikan misalnya dengan mengambil contoh Ekowisata Taman Nasional Gunung Halimun Salak (TNGHS). Merujuk pada Ekayani et al (2014a) Wisata alam di TNGHS Kabupaten Bogor telah lama dikembangkan. Banyak pihak terlibat dan memiliki kepentingan dengan pengembanganwisata alam tersebut. Berkembangnya partisipasimulti pihak dalam pengelolaan wisata alamTNGHS merupakan cerminan pentingnyaperanan wisata alam bagi perekonomian lokal.Banyak pihak mendapatkan manfaat dari kegiatanwisata tersebut.

Kajian lebih lanjut oleh Ekayani et al (2014b) menunjukkan bahwa pembayaran jasa lingkungan wisata alam di TNGHS dapat sebagai alternatif solusi benturan kepentingan antara konservasi dan pemenuhan ekonomi masyarakat, sepanjang wisata alam dapat memberikan manfaat bagi kedua belah pihak. Kondisi ini didukung oleh hal-hal sebagai berikut: 1) Jasa lingkungan berupa wisata alam di TNGHS memiliki nilai ekonomi tinggi, artinya TNGHS memiliki arti penting sebagai penyedia jasa wisata alam yang mengandalkan kelestarian dan keindahan alam; 2) Tarif tiket wisata sesuai kesediaan membayar pengunjung menunjukkan bahwa pengunjung masih bersedia membayar lebih dari tarif yang berlaku. Nilai surplus konsumen menunjukkan wisatawan mendapat kepuasan lebih dari harga yang dibayarkan; 3) Wisata alam TNGHS memberikan kontribusi penting bagi konservasi berupa dana konservasi dan pemenuhan ekonomi masyarakat berupa penyerapan tenaga kerja dan dampak ekonomi bagi perekonomian lokal; 4) Masyarakat akan turut serta menjaga kelestarian kawasan konservasi jika mendapat manfaat ekonomi dari kegiatan wisata alam.

Wacana tentang kegagalan pariwisata menimbulkan perdebatan mengenai paradigma pembangunan pariwisata yang berkembang dewasa ini yang dianggap kurang menguntungkan komunitas setempat. Pengembangan pariwisata yang baik harus memberikan keuntungan ekonomi, sosial, danbudaya kepada komunitas di sekitar destinasi. Kemudian lahirlah pemikiran untuk mengembangkan pariwisata yang lebih berpihak pada masyarakat yang kemudian dikenal dengan istilah Community Based Tourism (CBT) atau pariwisata berbasis komunitas. Melalui pengembangan CBT diharapkan industri pariwisata dapat menjadi instrumet pembangunan yang lebih menyejahterakan masyarakat. Secara global CBT tidak sekedar pengembangan pariwisata melainkan juga dikembangkan sebagai bagian dari program penanggulangan masalah kemiskinan di Afrika Selatan, Thailand, Dominika, Karibia, Jamaika, dan Barbados (Nurhidayati \& Fandeli, 2012).

Konsep CBT diadaptasi pula dalam ekowisata sehingga dikenal istilah Community Based Ecotourism (CBE) atau ekowisata berbasiskomunitas.Ekowisata berbasis masyarakat merupakan usahaekowisata yang menitikberatkan peran aktif komunitas (CIFOR, 2004; Hayati, 2014). Hal tersebut didasarkan kepada kenyataan bahwa masyarakat memiliki pengetahuan tentang alam serta budaya yang menjadipotensi dan nilai jual sebagai daya tarik wisata, sehingga pelibatanmasyarakat menjadi mutlak (Ditjen PDP-Depbudpar \& WWF-Indonesia, 2009).

Secara konseptual ekowisata menekankan pada prinsip dasar terintergrasi yang harus diperhatikan untuk menjamin keberhasilannya. Sehubungan dengan itu Ditjen PDP Depbudpar \& WWF-Indonesia (2009) telah mengeluarkan Panduan Prinsip dan Kriteria Ekowisata Berbasis Masyarakat. Ada lima prinsip yang perlu diperhatikan para pengelola dan pengembang, yaitu (1) Keberlanjutan ekowisata dari aspek ekonomi, sosial, dan lingkungan (Prinsip konservasi, 3 kriteria), (2) Pengembangan institusi masyarakat lokal dan kemitraan (Prinsip partisipasi masyarakat, 4 kriteria), (3) Ekonomi berbasis masyarakat (4 kriteria), (4) Prin- 
sip edukasi (4 kriteria), dan (5) Pengembangan dan penerapan rencana tapak dan kerangka kerja pengelolaan ekowisata (Prinsip wisata, 7 kriteria).

Panduan tersebut ternyata masih belum lengkap dan operasional, karena banyak prinsip yang mirip, dan belum tercakup sehingga bisa jadi akan menyebakan kegiatan analisis atau evaluasi yang dilakukan tidak maksimal. Oleh karena itu, Priono (2012) juga mengembangkan panduan yang relatif lebih operasional, dimana ada lima prinsip yang perlu diperhatikan, yaitu (1) Prinsip Konservasi (Prinsip Konservasi Alam dan Prinsip Konservasi Budaya), (2) Prinsip Partisipasi Masyarakat, (3) Prinsip Ekonomi, (4) Prinsip Edukasi , dan (5) Prinsip Wisata. Sehubungan dengan itu, penelitian ini bertujuan mengevaluasi implementasi 5 prinsip Ekowisata Berbasis Masyarakat dalam pengelolaan CMC, Sumbermanjing Wetan, Kabupaten Malang.

Evaluasi mengenai implementasi prinsip ekowisata berbasis masyarakat dalam pengelolaan Clungup Mangrove Conservation diharapkan bermanfaat bagiupayaupaya pengembangan produk dan konservasi kawasan ekowisata. Hal tersebut sangat penting agar pengembangan kawasan mampu memberikan manfaat karena sesuai dengan kebutuhan sehingga peningkatan kesejahteraan dan perekonomian masyarakat setempat dapat terpenuhi atau tercapai.

\section{Metode}

Penelitian ini dilakukan di kawasan obyek ekowisata Clungup Mangrove Conservation (CMC) terletak di Desa Tambakrejo, Kecamatan Sumbermanjing Wetan, Kabupaten Malang, Provinsi Jawa Timur. Luas kawasan CMC ini adalah $81 \mathrm{Ha}$ dan sempadan pantai seluas 117 hektar. CMC mengelola 3 pantai utama, yaitu Pantai Clungup, Pantai Gatra, dan Pantai Tiga Warna.Gambaran lokasi atau kondisi ketiga pantai yang dikelola oleh CMC ditunjukkan pada Gambar 1, Gambar 2, dan Gambar 3. Penelitian dilakukan pada bulan Oktober 2016.

Pengumpulan data dalam penelitian ini dilakukan dengan beberapa cara yang direkomendasikan oleh Soedigdo \& Priono (2013), yaitu 1) In-depth interview dengan narasumber yang terdiri dari pengelola, pengunjung, dan biro travel. 2) Angket/kuisioner, diisi oleh responden yang teridi dari pengelola, pengunjung, dan biro travel. 3) Observasi lapangan untuk melakukan pengamatan dan pengecekan terhadap ekowisata CMC, baik dalam hal atraksi wisata alam, amenitas, aksesibilitas, pasar (wisatawan/pengunjung) dan terhadap keterlibatan masyarakat dalam ekowisata. 4) Kajian pustaka dan dokumen. Peneliti mengkaji berbagai literatur yangterkait dengan kata kunci penelitian ini, misalnya Clungup Mangrove Center dan prinsip ekowisata berbasis masyarakat.

Informasi yang diperoleh selanjutnya dipergunakan untuk mengevaluasi implementasi prinsip ekowisata berbasis masyarakat yang mengacu kepada 5 Prinsip versi Priono (2012), yaitu (1) Prinsip Konservasi (Prinsip Konservasi Alam terdiri 6 kriteria dan Prinsip Konservasi Budaya (ada 4 kriteria), (2) Prinsip Partisipasi
Masyarakat (ada 7 kriteria), (3) Prinsip Ekonomi (ada 5 kriteria), (4) Prinsip Edukasi (terdiri 5 kriteria), dan (5) Prinsip Wisata (ada 6 kriteria). Sehubungan dengan itu, penelitian ini bertujuan mengetahui implementasi 5 prinsip Ekowisata Berbasis Masyarakat dalam pengelolaan CMC Desa Tambakrejo, Sumbermanjing Wetan, Kabupaten Malang.

Metode analisis data menggunakan paradigma penelitian deskriptif kualitatif berdasarkan teori-teori yang terkait dengan kata kunci-kata kunci penelitian. Menurut Priono (2012) ada tiga kriteria untuk menilai kondisi eksisting implementasi masing-masing prinsip dan aspek/kriteria, yaitu kurang, sedang, dan tinggi. Evaluasi implementasi prinsip ekowisata berbasis masyarakat dalam pengelolaan $\mathrm{CMC}$ oleh responden dilakukan dengan instrumen kuesioner yang menggunakan skala Likert dengan skala pilihan 1-4. Selanjutnya dihitung jumlah total dari masing-masing aspek/kriteria. Total skor diintepretasikan ke dalam tiga kategori, yaitu tinggi dengan rentang nilai $81 \%-100 \%$, sedang dengan rentang nilai $61 \%-80 \%$, dan rendah jika rentang nilai $\leq 60 \%$.

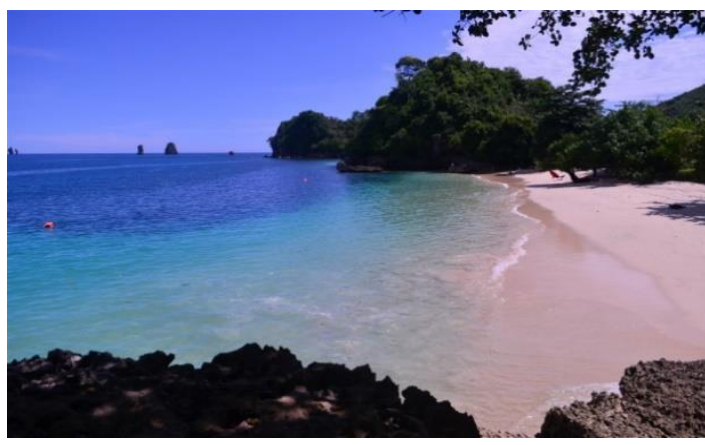

Gambar 1. Pantai Tiga Warna (Sumber: Mujtaba, 2016)

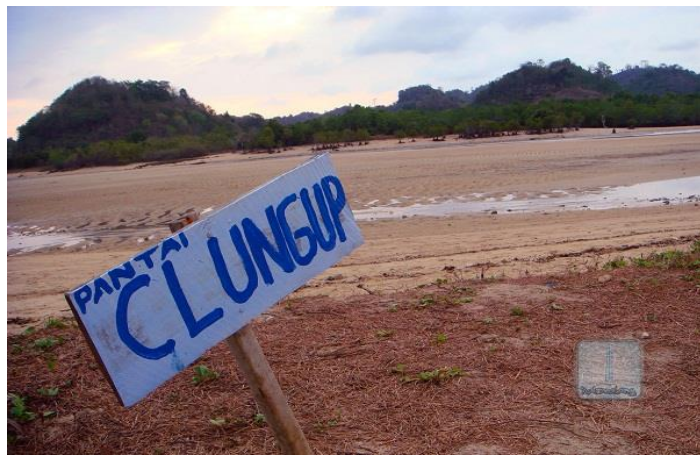

Gambar 2. Pantai Clugup

(Sumber: Arief, 2016) 


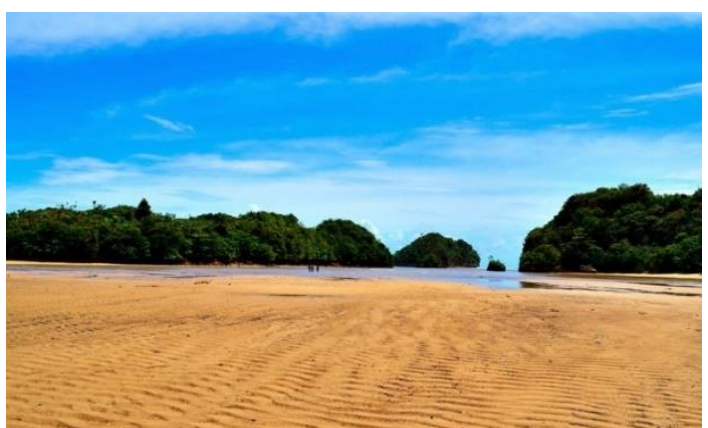

Gambar 3. Pantai Gatra

(Sumber: Wisata Pulau Jawa, 2016)

\section{Hasil dan Pembahasan}

Peneliti telah melakukan evaluasi terkait implementasiprinsip ekowisata berbasis masyarakat dalam pengelolaan CMC Desa Tambakrejo, Kecamatan Sumbermanjing Wetan, Kabupaten Malang, Jawa Timur yang masing-masing hasilnya disajikan pada Tabel 1 sampai dengan Tabel 5.

Berdasarkan Tabel 1 diketahui bahwa prinsip konservasi alam telah diperhatikan atau menjadi pertimbangan dalam pengelolaan CMC. Aspek atau kriteria dari prinsip konservasi alam berada dalam kondisi sedang (3 kriteria) dan tinggi (3 kriteria). Hal ini menunjuk bahwa pengelola telah memiliki kepedulian, tanggung jawab, dan komitmen terhadap pelestarian alam serta pembangunan yang mengikuti kaidah ekologis.

Hal ini sesuai dengan penuturan narasumber 1 (pengelola), sebagai berikut:

\footnotetext{
"Keberadaan mangrove sangat penting bagi lingkungan pesisir. Selain untuk menghindari abrasi laut, mangrove berfungsi sebagai untuk memulihkan ekosistem yang berada di pesisir laut pantai selatan Kabupaten Malang. Konsistensi kegiatan konservasikawasan mangrove pesisir pantai yang dilakukan oleh Lembaga Masyarakat Konservasi Bhakti Alam Sendang Biruini semakin berkembanghingga melahirkan gerakan baru bernama Clungup Mangrove Conservation. Disamping eberhasilan dalam melakukan upaya konservasi, kelompok kami juga berhasil mengelola kawasan konservasi tersebut untuk tujuan wisata terbatas. Kami tidak berorientasi pada bisnis dan tetap mempertimbangkan prinsip konservasi.Semua langkah kami ini untuk menggugah seluruh lapisan masyarakat agar memiliki kepedulian terhadap ekosistem alam yang ada. Sehingga sumber daya alam ini dapat terjaga dengan baik sebagai warisan generasi ke depan. Tujuan kami selain sebagai sarana wisata edukasi juga untuk mengajak wisatawan. Agar memiliki kepedulian terhadap kelangsungan hutan mangrove yang saat ini banyak yang rusak akibat ulah orang tidak bertanggung jawab," (W1/N1/10/2016).
}

Sebagai wujud upaya meminimalkan dampak negatif yang ditimbulkan maka CMC telah membuat sistem zonasi dan selanjutnya membatasi jumlah pengunjung sesuai dengan ketersediaan sarana, fasilitas, serta sesuai dengan daya dukung lingkungan. Berdasarkan observasi diperoleh informasi bahwa jumlah pengunjung ke CMC telah dibatasi. Rombongan dengan jumlah besar harus menginformasikan jadwal kunjungan jauh-jauh hari sebelumnya sehingga waktu kunjungan mereka dapat diatur oleh pengelola. CMC bahkan memberlakukan ketentuan khusus untuk pengunjung yang akan mendatangi Pantai Tiga Warna, yaitu 1 kelompok harus terdiri dari 10 orang dan setiap harinya hanya maksimal ada 10 kelompok pengunjung. Sistem yang diberlakukan adalah kuota sehingga calon pengunjung harus melakukan reservasi atau membooking terlebih dahulu.

Tabel 1. Prinsip Konservasi

\begin{tabular}{|c|c|c|c|c|}
\hline \multirow{2}{*}{ No } & \multirow{2}{*}{ Aspek/Kriteria } & \multicolumn{3}{|c|}{ Kondisi Eksisting } \\
\hline & & Tinggi & Sedang & Rendah \\
\hline \multicolumn{5}{|c|}{ Prinsip Konservasi Alam } \\
\hline 1 & $\begin{array}{l}\text { Memperhatikan kuali- } \\
\text { tasdaya dukung ling- } \\
\text { kungan kawasan tujuan, } \\
\text { melalui permintakatan } \\
\text { (zonasi). }\end{array}$ & $v$ & & \\
\hline 2 & $\begin{array}{l}\text { Mengelola jumlah } \\
\text { pengunjung, sarana dan } \\
\text { fasilitas sesuai dengan } \\
\text { daya dukung lingkungan } \\
\text { daerah tujuan. }\end{array}$ & & $\checkmark$ & \\
\hline 3 & $\begin{array}{l}\text { Meningkatkan kesadaran } \\
\text { dan apresiasi para pelaku } \\
\text { terhadap lingkungan alam } \\
\text { dan budaya. }\end{array}$ & & $\checkmark$ & \\
\hline 4 & $\begin{array}{l}\text { Memanfaatkan sumber } \\
\text { daya secara lestari dalam } \\
\text { penyelenggaraan kegiatan } \\
\text { ekowisata. }\end{array}$ & $v$ & & \\
\hline 5 & $\begin{array}{l}\text { Meminimumkan dampak } \\
\text { negatif yang ditimbulkan, } \\
\text { dan bersifat ramah ling- } \\
\text { kungan. }\end{array}$ & $v$ & & \\
\hline 6 & $\begin{array}{l}\text { Mengelola usaha secara } \\
\text { sehat. }\end{array}$ & & v & \\
\hline \multicolumn{5}{|c|}{ Prinsip Konservasi Budaya } \\
\hline 1 & $\begin{array}{l}\text { Menerapkan kode etik } \\
\text { ekowisata bagi wisatawan, } \\
\text { pengelola dan } \\
\text { pelaku usaha ekowisata. }\end{array}$ & $v$ & & \\
\hline 2 & $\begin{array}{l}\text { Melibatkan masyarakat } \\
\text { setempat dan pihak-pihak } \\
\text { lainnya (multi stakehold- } \\
\text { ers dalam penyusunan } \\
\text { kode etik wisatawan, } \\
\text { pengelola dan pelaku } \\
\text { usaha ekowisata. }\end{array}$ & & 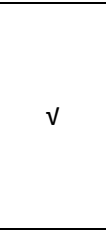 & \\
\hline 3 & $\begin{array}{l}\text { Melakukan pendekatan, } \\
\text { meminta saran-saran dan } \\
\text { mencari masukan dari } \\
\text { tokoh/pemuka masyarakat } \\
\text { setempat pada tingkat pal- } \\
\text { ing awal sebelum memulai } \\
\text { langkah-langkah dalam } \\
\text { proses pengembangan } \\
\text { ekowisata. }\end{array}$ & & $v$ & \\
\hline 4 & $\begin{array}{l}\text { Melakukan penelitian dan } \\
\text { pengenalan aspek aspek } \\
\text { sosial budaya masyarakat } \\
\text { setempat sebagai bagian } \\
\text { terpadu dalam proses } \\
\text { perencanaan dan pengel- } \\
\text { olaan ekowisata. }\end{array}$ & & & $v$ \\
\hline
\end{tabular}


Berdasarkan kondisi tersebut, maka pengelola CMC perlu memberlakukan pembatasan jumlah kunjungan sesuai carryng capacity atau daya dukung. Menurut Vibriyanto et al (2015) jumlah kunjungan wisata saat hari libur (peak season) yang lebih tinggi dibandingkan hari biasa (low season) berpotensi mengakibatkan over carrying capacity yang berdampak negatif berupa degradasi lingkungan, bencana alam, dan hilangnya kegiatan wisata alam. Salah satu upaya mengatasi over carrying capacity dapat dilakukan segmentasi harga saat peak dan low season. Harga tiket pada peak season ditetapkan lebih tinggi daripada harga tiket low season. Penentuan harga tiket pada peak season dapat ditetapkan sesuai dengan Willingness to Pay (WTP) pengunjung untuk membayar lebih, sedangkan pada saat low season ditetapkan harga tiket yang berlaku saat ini. Diharapkan adanya distribusi jumlah pengunjung yang lebih berimbang pada saat peak season dan low season karena pengunjung yang tidak bersedia membayar lebih dapat berkunjung pada low season.

Hal ini juga sejalan dengan Nurita et al (2015) bahwa hasil penjualan tiket dapat digunakan untuk kegiatan konservasi. Dengan demikian perlu dikaji WTP pengunjung terhadap wisata alam. Metode yang digunakan untuk mendapatkan nilai WTP pengunjung misalnya adalah metode bidding game. Metode tersebut dilakukan dengan menawarkan harga tiket secara bertahap hingga mendapatkan nilai WTP maksimal. Penentuan harga tiket dapat mengontrol jumlah kunjungan agar tidak over carrying capacity.

Narasumber 1 (pengelola) menyampaikan pula sebagai berikut:

\footnotetext{
"Pengunjung harus ijin dan didampingi petugas pemandu. Karena terdapat area konservasiberupa Penyu dan Terumbu Karang.Pantai tiga warna telah ditetapkan sebagai marine protected area terumbu karang. Kami melakukan adanya transplantasi terumbu karang."(W2/N1/10/2016).
}

Informasi yang disampaikan oleh Narasumber 1 (pengelola) didukung pula oleh Narasumber 2 (biro travel), sebagai berikut:

\begin{abstract}
"Satu hal yang patut diapresiasi untuk pihak pengelola yaitu mereka tidak mengeksploitasi keindahan Pantai Tiga Warna ini secara membabibuta. Terbukti dengan motto mereka "No negotiation if fullbooked" pihak pengelola tidak terlena dengan penghasilan yang besar. Ada kuota maksimal pengunjung di setiap harinya, Pengelola menerapkan sistem reservasi dan ada batasan pengunjung. Tidak boleh melebihi 100 orang per gelombang. Maksimal per grup 10 orang. Tidak boleh lebih.Jika pas weekend usahakan reservasi 1 bulan sebelumnya. Hari biasa usahakan 1 minggu sebelumnya. Tentunya itu semua demi menjaga kelestarian dan kealamian dari wisata pantai di Malang ini." (W1/N2/10/2016).
\end{abstract}

Sehubungan dengan itu, menurut Natural Sunrise Tour (2015) sebagai wujud tanggung jawab dan komitmen terhadap pelestarian alam, CMC memberlakukan beberapa peraturan dan persyaratan, yaitu 1) Sistem Check List Barang Bawaan. Semua barang bawaan pengunjungakan diperiksa oleh petugas, terutama makanan dan minuman berbungkus yang dapat menimbulkan sampah. Semua barang tersebut kemudian dicatat dan nantinya ketika di pintu keluar, bungkus- bungkus makanan tersebut akan diperiksa dan dicocokkan dengan list awal. Jika ada sampah yang tertinggal maka pengunjung akan dikenakan denda sebesar Rp.100.000,- per item. Contoh Check List disajikan pada Gambar 4.

Ada pula berbagai peraturan yang harus ditaati oleh para pengunjung, yaitu 1) Tidak Meninggalkan Sampah, sehingga barang yang dibawa masuk harus sesuai dengan yang dibawa pulang. 2) Berpartisipasi dalam Melestarikan Alam, dimana setiap pengunjung juga diwajibkan membayar tiket masuk senilai 1 pohon mangrove sebesar Rp.10.000. 3) Sistem Tutup/Libur Kunjungan. Sejak awal bulan September 2015, pihak pengelola memberlakukan sistem libur satu hari dalam satu minggu dan hari yang dipilih adalah hari kamis. Hari kamis digunakan oleh pengelola untuk menanam pohon, transplantasi karang, membenahi fasilitas, dan membersihkan sampah-sampah. 4) Waktu Kunjungan. Setiap rombongan hanya diberi waktu 2 jam untuk menikmati semua panorama keindahan pantai. Tour Guideakan mengingatkan jika waktu sudah habis. 5. Camping. Kegiatan ini hanya diperbolehkan di Pantai Clungup dan Pantai Gatra dengan biaya sewa lahan Rp. 25.000,- dan sewa tenda Rp.25.000,-. Pengunjung dilarang camping di Pantai Tiga Warna karena wilayah ini termasuk dalam kawasan konservasi.

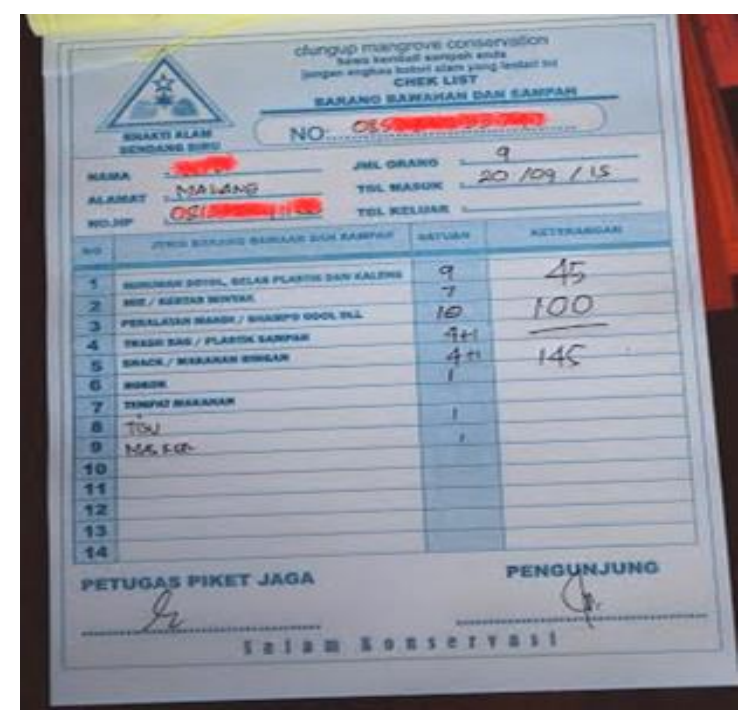

Gambar 4. Contoh Check List Barang Bawaan Pengunjung (Sumber: Wisata Pulau Jawa, 2016)

Berdasarkan Tabel 1 dan Gambar 4 diketahui pula bahwa pengelola telah berupaya memperhatikan prinsip konservasi budaya. Sebagaimana hasil wawancara yang dilakukan, pengelola mengatakan bahwa mereka telah menerapkan berbagai peraturan dan etika yang harus diperhatikan oleh tim pengelola serta oleh para pengunjung. Peraturan tersebut disusun, ditetapkan bersama oleh kelompok pengelola, melibatkan masyarakat, dan telah berkonsultasi dengan tokoh masyarakat setempat.

Pengembangan dan pengelolaan ekowisata harus mampu memelihara, melindungi, dan atau berkontribusi untuk memperbaiki sumber daya alam. Pengelola harus pula memiliki kepedulian, tanggung jawab dan 
komitmen terhdap pelestarian lingkungan alam atau memperhatikan kaidah ekologis dan budaya serta tradisi masyarakat setempat, melaksanakan kaidah-kaidah usaha yang bertanggung jawab, dan ekonomi berkelanjutan (Priono, 2012).

Aspek atau kriteria "melakukan penelitian dan pengenalan aspek aspek sosial budaya masyarakat setempat sebagai bagian terpadu dalam proses perencanaan dan pengelolaan ekowisata" masih kurang dilakukan. Hal ini mengingat bahwa pengelola masih memiliki keterbatasan pengetahuan terkait hal tersebut. Menurut narasumber, akan sangat bermanfaat bagi mereka apabila ada pihak ketiga khususnya dari perguruan tinggi yang membantu mereka terkait aspek tersebut. sehubungan dengan itu, menurut Hilman (2016) konservasi budaya biasanya lebih menekankan pada identitas budaya yang coba ditampilkan, secara natural, dan apa adanya, sehingga nampak jelas bagaimana masyarakat hidup, bersosialisasi dan membangun komunikasi dengan komunitasnya. Selain itu apsek konservais budaya juga dituntut untuk dapat menyentuh komponen - komponen kawasan secara mendasar, yaitu: a). Pemberdayaan masyarakat pelaku wisata budaya. b). Pengembangan pusat - pusat kegiatan wisata sebagai titik pertumbuhan. c). Pengembangan sarana dan prasarana yang menunjang. d). Adanya keterpaduan antar kawasan mendukung upaya peningkatan dan pelestarian daya dukung lingkungan serta sosial dan budaya setempat. e). Adanya keterpaduan kawasan wisata budaya dengan rencana tata ruang wilayah daerah.

Sebagai bentuk riil dari teori tersebut, dalam tataran aplikasi menurut Hilman (2016) langkah-langkah berikut perlu dilakukan, yaitu 1). Pembentukan komunitas masyarakat atau meneruskan kelompok sosial yang ada, 2). Kemudian komunitas tersebut memerakan potensi yang ada berupa, potensi budaya, ekonomi, sumber daya alam, dan lain sebagainya, 3). Setelah itu dibuatlah desain dan mekanisme pengelolaan wisata budaya untuk mendukung wisata utama, 4). Kemudian membuat peraturan desa atau produk hukum atau istilah lain, yang mengatur soal pengelolaan, retribusi, dan juga lainsebagainya, 5). Melakukan pelaksanaan kegiatan wisata budaya, dengan melakukan publikasi dokumentasi, 6). Melanjutkan dengan pengawasan dan evaluasi terhadap pelaksanaan wisata budaya, selain itu dalam pelaksanaannya harus ditekankan peran serta komunitas, khususnya warga masyarakat untuk mengelola dengan konsep dari masyarakat lokal, oleh masyarakat lokal, dan untuk masyarakat lokal.

Berdasarkan Tabel 2 diketahui bahwa prinsip partisipasi masyarakat belum maksimal (sebagian besar kategori sedang). Namun demikian, pada dasarnya CMC telah berupaya memperhatikan prinsip partisipasi masyarakat meskipun belum maksimal (CMC didirikan atas prakarsa masyarakat, bukan pemerintah). Hal ini mengingat bahwa CMC sepenuhnya berasal dari kegiatan masyarakat setempat yang kemudian terus berkembang. Sebagaimana dijelaskan dalam sejarah CMC, pembukaan ekowisata ini adalah murni wujud ekowisata yang berasal dari keinginan masyarakat dan dilakukan oleh masyarakat. Hal ini sesuai dengan aspek/kriteria ketiga yaitu "menggugah prakarsa dan aspirasi masyarakat setempat untuk pengembangan ekowisata" yang memiliki nilai tinggi.

Tabel 2. Prinsip Partisipasi Masyarakat

\begin{tabular}{|c|c|c|c|c|}
\hline \multirow{2}{*}{ No } & \multirow{2}{*}{ Aspek/Kriteria } & \multicolumn{3}{|c|}{ Kondisi Eksisting } \\
\hline & & Tinggi & Sedang & Rendah \\
\hline 1 & $\begin{array}{l}\text { Melakukan penelitian dan } \\
\text { perencanaan terpadu dalam } \\
\text { pengembangan ekowisata. }\end{array}$ & & & $v$ \\
\hline 2 & $\begin{array}{l}\text { Membangun hubungan } \\
\text { kemitraan dengan masyara- } \\
\text { kat setempat dalam proses } \\
\text { perencanaan dan pengel- } \\
\text { olaan ekowisata. }\end{array}$ & & v & \\
\hline 3 & $\begin{array}{l}\text { Menggugah prakarsa dan } \\
\text { aspirasi masyarakat setem- } \\
\text { pat untuk pengembangan } \\
\text { ekowisata. }\end{array}$ & v & & \\
\hline 4 & $\begin{array}{l}\text { Memberi kebebasan } \\
\text { kepada masyarakat untuk } \\
\text { bisa menerima atau me- } \\
\text { nolak pengembangan } \\
\text { ekowisata. }\end{array}$ & & v & \\
\hline 5 & $\begin{array}{l}\text { Menginformasikan secara } \\
\text { jelas dan benar konsep dan } \\
\text { tujuan pengembangan } \\
\text { ekowisata. }\end{array}$ & & v & \\
\hline 6 & $\begin{array}{l}\text { Membuka kesempatan un- } \\
\text { tuk melakukan dialog } \\
\text { dengan seluruh pihak yang } \\
\text { terlibat (multi-stakehold- } \\
\text { ers) dalam proses } \\
\text { perencanaan dan pengel- } \\
\text { olaan ekowisata. }\end{array}$ & & v & \\
\hline 7 & $\begin{array}{l}\text { Membentuk kerjasama } \\
\text { dengan masyarakat setem- } \\
\text { pat untuk melakukan } \\
\text { pengawasan dan pencega- } \\
\text { han terhadap dilanggarnya } \\
\text { peraturan yang berlaku. }\end{array}$ & & $v$ & \\
\hline
\end{tabular}

Narasumber 1 (pengelola) menuturkan sebagai berikut:

"Awalnya penyadaran masyarakat setempat yang kami lakukan melalui sosialisasi door to dooruntuk mengajak masyarakat sekitar melakukan konservasi. Meski tidak semua masyarakat memiliki antusias yang tinggi, setidaknya sudah bertambah masyarakat yang bergabung melakukan konservasi. Saat ini kami bersama sekitar 25 orang warga lokal yang berhasil direkrut. Yang terlibat sebenarnya bahkan lebih dari itu, missalnya jika dihitung dengan tukan ojek dan tenaga lainnya. Kami rutin melakukan penanaman bakau di kawasan ini dari hasil pembibitan sendiri secara sukarela." (W2/N1/10/2016)

Sementara itu, narasumber 3 (pengelola, tour guide) juga menyampaikan sebagai berikut:

\footnotetext{
"Masyarakat yang terlibat di sini besar hati membantu mengembangkan dan rela tidak di gaji. Awalnya bahkan kami dianggap orang gila oleh tetangga dan masyarakat lainnya. Kami sempat dihina karena tidak mendapat gaji. Namun, kami sangat puas, apalagi misalnya Ibu Menteri Kelautan dan Perikanan Indonesia dan Pak Menteri Olahraga Indonesia pernah datang ke wilayah ini." (W1/N3/10/2016)
}

Aspek atau kriteria yang masih rendah adalah "melakukan penelitian dan perencanaan terpadu dalam pengembangan ekowisata". Keterbatasan sumberdaya manusia dan umur obyek ekowisata yang masih 4 tahun menyebabkan pengelola belum melakukan penelitian 
dan perencanaan terpadu untuk pengembangan ekowisata CMC. Sementara itu, aspek/kriteria lain sudah menunjukkan kondisi yang mulai baik (nilai sedang). Partisipasi masyarakat akan menjadi kekuatan dalam pengelolaan CMC bila pengelola mampu memaksimalkan potensi ini dengan cara meningkatkan upaya membangun hubungan dengan masyarakat, mennjukkan sikap terbuka dan memberikan informasi yang tepat atau jujur (jelas dan benar), memaksimalkan dialog dalam proses perencanaan dan pengelolaan, dan aktif bekerjasama dengan segenap lapisan masyarakat setempat dalam hal pengawasan dan pemberlakuan peraturan dan pencegahan pelanggaran. Apabila hal ini tidak dilakukan maka bisa jadi partisipasi masyarakat yang mulai muncul justru akan menghilang dan akan menjadi hambatan besar pagi pengelolaan CMC. Hal ini seharusnya direspon oleh pihak terkait, seperti pemerintah daerah (melalui dinas-dinas terkait) dan lembaga pendidikan (khususnya perguruan tinggi).

Tabel 3. Prinsip Ekonomi

\begin{tabular}{|c|c|c|c|c|}
\hline \multirow{2}{*}{ No } & \multirow{2}{*}{ Aspek } & \multicolumn{3}{|c|}{ Kondisi Eksisting } \\
\hline & & Tinggi & Sedang & Rendah \\
\hline 1 & $\begin{array}{l}\text { Membuka kesempatan } \\
\text { kepada masyarakat setem- } \\
\text { pat untuk membuka usaha } \\
\text { ekowisata dan menjadi } \\
\text { pelaku-pelaku ekonomi } \\
\text { kegiatan ekowisata baik } \\
\text { secara aktif maupun pasif. }\end{array}$ & & $\sqrt{ }$ & \\
\hline 2 & $\begin{array}{l}\text { Memberdayakan masyara- } \\
\text { kat dalam upaya pening- } \\
\text { katan usaha ekowisata un- } \\
\text { tuk kesejahteraan } \\
\text { penduduk setempat. }\end{array}$ & & v & \\
\hline 3 & $\begin{array}{l}\text { Meningkatkan ketrampilan } \\
\text { masyarakat setempat dalm } \\
\text { bidang-bidang yang berkai- } \\
\text { tan dan menunjang } \\
\text { pengembangan ekowisata. }\end{array}$ & & & v \\
\hline 4 & $\begin{array}{l}\text { Menekan tingkat ke- } \\
\text { bocoran pendapatan (leak- } \\
\text { age) serendah-rendahnya. }\end{array}$ & & V & \\
\hline 5 & $\begin{array}{l}\text { Meningkatkan pendapatan } \\
\text { masyarakat. }\end{array}$ & & v & \\
\hline
\end{tabular}

Pengembangan ekowisata harus mampu memberikan manfaat untuk masyarakat setempat dan menjadi penggerak pembangunan ekonomi di wilayahnya untuk memastikan bahwa daerah yang masih alami dapat mengembangkan pembangunan yang berimbang (balance development) antara kebutuhan pelestarian lingkungan dan kepentingan semua pihak. Pengembangan Ekowisata juga harus mampu memberikan manfaat yang optimal kepada masyarakat setempat dan berkelanjutan (Priono, 2012). Tabel 3 menunjukkan bahwa pengelolaan CMC belum memberikan kesempatan seluas-luasnya kepada masyarakat untuk terlibat sebagai pelaku-pelaku ekonomi kegiatan ekowisata sehingga kesejahteraan belum meningkat secara signifikan. Empat aspek dalam prinsip ekonomi ini memiliki nilai sedang dan satu aspek memiliki nilai kurang. Namun demikian, aspek ini telah dipikirkan oleh pengelola CMC. Hal ini sejalan dengan penuturan narasumber 4 (pengelola), sebagai berikut:
"Konservasi ekosistem mangrove baiknya juga memperhatikan sisi ekonomi masyarakat. Sebab, konservasi dan perlindungan alam akan sulit diwujudkan tanpa adanya dukungan masyarakat. Kami coba mengkombinasikan perlindungan dan pelestarian lingkungan dengan kegiatan yang menghasilkan nilai ekonomi bagi masyarakat. Ini penting, agar pengelolaan ini berumur panjang." (W1/N4/10/2016).

Narasumber 1 juga menyampaikan informasi sebagai berikut:

\footnotetext{
"Melalui ekowisata, teman-teman yang dulunya merambah mangrove, kami alihkan menjadi pemandu wisata dan lainnya. Menanam itu mudah. Menjaga dan merawat itu yang berat, karena harus ada kolaborasi semua pihak, terutama warga sini." (W3/N1/10/2016).
}

Pengelolaan dan pengembangan suatu obyek wisata harus memenuhi faktor pelibatan masyarakat lokal sebagai partisipan aktif. Faktor ini sangat krusial, sebab partisipasi merupakan garansi bagi keberlanjutan pembangunan pariwisata (Murdiastuti et al., 2014). Masyarakat lokal menjadi kunci karena keberlangsungan fungsi ekologi membutuhkan peran mereka (Andronicus et al., 2016). Berdasarkan observasi yang dilakukan, diketahui bahwa masyarakat secara terbatas mulai terlibat dalam pengelolaan ekowisata CMC, sebagai tour guide, pedagang/membuka warung, tukang ojek, tukang parkir, penjaga toilet, penyewaan fasilitas snorkeling, petugas pemeriksa (check) barang bawaan pengunjung, dan ada pula yang menjadikan rumahnya sebagai penginapan atau homestay. Sebagai upaya penerapan prinsip ekonomi maka pengelola menetapkan tarif kepada pengunjung, yaitu tiket yang dimaksudkan untuk donasi 1 bibit mangrove Rp. 10.000, bila ingin ke pantai tiga warna maka diharuskan didampingi 1 orang local guide dengan biaya untuk per 10 orang sebesar Rp. 100.000 , biaya sewa alat camping atau tenda Rp. 25.000 per malam, biaya sewa lahan Rp. 25.000 per malam, parkir motor Rp. 5.000, parkir mobil Rp. 10.000, ongkos ojek Rp. 5.000 per orang, dan biaya sewa snorkle plus life vest mulai Rp. 15.000.

Berdasarkan kenyataan tersebut dapat dikatakan bahwa pengelola CMC mulai mempertimbangkan aspek PES (Payment for Ecosystem Services/Pembayaran Jasa Lingkungan). Menurut Idrus et al (2016) pembayaran jasa lingkungan perlu diterapkan sebagai upaya perlindungan ekosistem termasuk mangrove dan daerah pesisir. Hal ini dikarenakan tingginya pemanfaatan jasa lingkungan, yang apabila tidak dikelola dengan benar dapat berpotensi mengancam kelestarian lingkungan yang menjadi obyek wisata alam. Pada dasarnya, pembayaran jasa lingkungan merupakan skema yang bertujuan untuk merestorasi dan melindungi ketersediaan barang dan jasa lingkungan yang berkelanjutan.

Berdasarkan pengamatan terhadap penerapan prinsip ekonomi ini, hal yang sangat lemah adalah ketrampilan masyarakat setempat dalam bidang-bidang yang berkaitan dan menunjang pengembangan ekowisata. Masyarakat masih perlu mendapatkan pendampingan dari pihak-pihak terkait sehingga mampu memaksimalkan potensi yang ada sehingga keberadaan ekowisata CMC benar-benar memberi dampak maksimal bagi 
masyarakat setempat, sebagaimana layaknya beberapa daerah yang telah maju di Malang Selatan, daerah-daerah lain di Malang, Jawa Timur, dan bahkan di Indonesia.

Upaya konservasi dalam pengembangan ekowisata juga diharapkan memberi kemanfaatan ekonomi secara berkelanjutan tanpa harus mengorbankan alam. Berkaitandengan nilai ekonomi, jikapotensi flora fauna bersama-sama dengan objek fisiknya dikembangkan menjadi objek wisata, maka akan mendatangkan keuntungan ekonomi yang besar tanpa harus melakukanpengrusakan ekosistem (Achmad et al., 2012). Kegiatan ekowisata yang dilakukan secara serius dan benar akan memberikan lapangan pekerjaan bagi warga setempat, dan membuka peluangusaha/dagang bagi masyarakat lokal. Penyelenggaraan ekowisata memberikan manfaat untuk masyarakat setempat dan bahkan menjadi lokomotif pembangunan ekonomi di wilayahnya.Ekowisata dapat menjadi sumber pendapatan bagi pembangunan ekonomi secara berkesinambungan. Selain usaha dagang, masyarakat sekitar juga mendapat kemanfaatan ekonomi dari penyediaan jasa lain, misalnya home staydi zona pemanfaatan (Palmaet al., 2012).

\begin{tabular}{|c|c|c|c|c|}
\hline \multirow{2}{*}{ No } & \multirow{2}{*}{ Aspek } & \multicolumn{3}{|c|}{ Kondisi Eksisting } \\
\hline & & Tinggi & Sedang & Rendah \\
\hline 1 & $\begin{array}{l}\text { Mengoptimalkan keunikan } \\
\text { dan kekhasan daerah se- } \\
\text { bagai daya tarik wisata. }\end{array}$ & & $\sqrt{ }$ & \\
\hline 2 & $\begin{array}{l}\text { Memanfaatkan dan men- } \\
\text { goptimalkan pengetahuan } \\
\text { tradisional berbasis peles- } \\
\text { tarian alam dan budaya } \\
\text { serta nilai-nilai yang dikan- } \\
\text { dung dalam kehidupan } \\
\text { masyarakat sehari-hari se- } \\
\text { bagai nilai tambah. }\end{array}$ & & $\sqrt{ }$ & \\
\hline 3 & $\begin{array}{l}\text { Mengoptimalkan peran } \\
\text { masyarakat sebagai inter- } \\
\text { preter lokal dari produk } \\
\text { ekowisata. }\end{array}$ & & $\sqrt{ }$ & \\
\hline 4 & $\begin{array}{l}\text { Memberikan pengalaman } \\
\text { yang berkualitas dan ber- } \\
\text { nilai bagi pengunjung. }\end{array}$ & $\sqrt{ }$ & & \\
\hline 5 & $\begin{array}{l}\text { Dikemas ke dalam bentuk } \\
\text { dan teknik penyampaian } \\
\text { yang komunikatif dan ino- } \\
\text { vatif. }\end{array}$ & & & V \\
\hline
\end{tabular}

Pengembangan ekowisata harus mengandung unsur pendidikan untuk mengubah sikap atau perilaku seseorang menjadi memiliki kepedulian, tanggung jawab dan komitmen terhadap pelestarian lingkungan (Nugraha et al., 2015; Muliya et al., 2016). Pengembangan ekowisata juga harus meningkatkan kesadaran dan apresiasi terhadap alam, nilai-nilai peninggalan sejarah dan budaya, serta memberikan nilai tambah dan pengetahuan bagi pengunjung, masyarakat dan para pihak yang terkait (Priono, 2012).

Berdasarkan Tabel 4, prinsip edukasi masih lemah meskipun pengelola telah berupaya mengimplementasikan dan oleh karena itu harus diapresiasi. Prinsip edukasi harus terus dikembangkan atau dioptimalkan.
Kekhasan daerah masih harus terus ditonjolkan, termasuk dalam hal ini adalah kearifan lokal masyarakat setempat yang mungkin saja tidak dimiliki oleh masyarakat di daerah lain, sehingga akan semakin menjaring minat pengunjung karena mereka yang datang akan memperoleh pengalaman baru dan bernilai. Informasi mengenai berbagai hal (keunggulan dan potensi) yang ada di CMC belum dikemas dalam bentuk dan teknik penyampaian yang komunikatif dan inovatif, sehingga selama ini informasi hanya bersifat dari mulut ke mulut.

Pengembangan ekowisata harus dapat memberikan kepuasan pengalaman kepada pengunjung untuk memastikan usaha ekowisata dapat berkelanjutan (Sumaraw et al., 2016). Selain itu pengembangan ekowisata juga harus mampu menciptakan rasa aman, nyaman dan memberikan kepuasan serta menambah pengalaman bagi pengunjung (Priono, 2012).Hal ini dikenal dengan prinsip wisata, sebagai mana disajikan pada Tabel 5.

Tabel 5. Prinsip Wisata

\begin{tabular}{|c|c|c|c|c|}
\hline \multirow{2}{*}{ No } & \multirow{2}{*}{ Aspek } & \multicolumn{3}{|c|}{ Kondisi Eksisting } \\
\hline & & Tinggi & Sedang & Rendah \\
\hline 1 & $\begin{array}{l}\text { Mengoptimalkan keunikan } \\
\text { dan kekhasan daerah se- } \\
\text { bagai daya tarik wisata. }\end{array}$ & & $\sqrt{ }$ & \\
\hline 2 & $\begin{array}{l}\text { Membuat Standar Prosedur } \\
\text { Operasi (SPO) untuk } \\
\text { pelaksanaan kegiatan di } \\
\text { lapangan. }\end{array}$ & & & $v$ \\
\hline 3 & $\begin{array}{l}\text { Menyediakan fasilitas yang } \\
\text { memadai sesuai dengan } \\
\text { kebutuhan pengunjung, } \\
\text { kondisi setempat dan men- } \\
\text { goptimalkan kandungan } \\
\text { material lokal. }\end{array}$ & & & $\checkmark$ \\
\hline 4 & $\begin{array}{l}\text { Memprioritaskan kebersi- } \\
\text { han dan kesehatan dalam } \\
\text { segala bentuk pelayanan, } \\
\text { baik fasilitas maupun jasa. }\end{array}$ & & $\checkmark$ & \\
\hline 5 & $\begin{array}{l}\text { Memberikan kemudahan } \\
\text { pelayanan jasa dan infor- } \\
\text { masi yang benar. }\end{array}$ & & $\checkmark$ & \\
\hline 6 & $\begin{array}{l}\text { Memprioritaskan kerama- } \\
\text { han dalam setiap pela- } \\
\text { yanan. }\end{array}$ & & $\sqrt{ }$ & \\
\hline
\end{tabular}

Terkait dengan Tabel 5 yaitu penerapan prinsip wisata, pengelola CMC telah berupaya memunculkan keunikan dan kekhasan daerah sebagai daya tarik wisata, dalam hal ini adalah keunikan mangrove dan pantainya. Namun demikian, sebagian besar aspek masih dalam kategori sedang, sehingga dapat dikatakan belum maksimal. Pengelola juga berupaya memprioritaskan kebersihan dan kesehatan dalam segala bentuk pelayanan, baik fasilitas maupun jasa, meskipun belum maksimal atau perlu ditingkatkan secara konsisten. Pada kenyataannya beberapa fasilitas penunjang masih kurang. Hal ini juga dirasakan oleh pengunjung, dimana narasumber 5 (pengunjung) menuturkan sebagai berikut: 
"Fasilitas masih sangat minim di Pantai Tiga Warna, dikarenakan untuk masyarakat umum pantai ini juga masih tergolong baru, toliet atau tempat bilas di lokasi Pantai Tiga Warna tidak ada.Kita hanya bisa temui di sekitar pintu masuk utama Clungup Mangrove Conservation. Jadi biasanya kita harus mengantri lama, sementara toiletnya juga kurang bersih dan sangat sempit. Ada pula 1 toilet atau tempat bilas di sekitar Pantai Clungup. Di pantai Clungup hanya ada 1 warung, yang menjual mi instant, mibuman instant, kantong plastik untuk tempat pakaian kotor atau basah, dan air mineral. Arungnya hanya menyediakan seadanya." (W1/N5/10/2016).

Pengelola berupaya memberikan kemudahan pelayanan jasa dan informasi yang benar dan memprioritaskan keramahan dalam setiap pelayanan. Namun demikian, Standard Operating Procedures (SOP) untuk pelaksanaan kegiatan di lapangan juga belum dibuat atau belum tersedia, meskipun dalam prakteknya mereka memiliki aturan tak tertulis yang disepakati oleh tim.

Menurut Meilani \& Muntasib (2013) agar ekowisata di Indonesia mampu bersaing dengan berbagai negara lain di dunia, maka para pengelola harus mampu menunjukkan keunggulan dan menciptakan competitive advantage. Salah satu wujud upaya yang dilakukan adalah memastikan tata kelola yang baik (good governance). Hal ini berarti bahwa semua pihak menghasilkan kinerja efektif sesuai dengan fungsi dan perannya yang didefinisikan dengan jelas dan tertuang dalam suatu Prosedur Operasional Baku (POB) atau Standard Operating Procedures (SOP). Sejalan dengan itu, menurut Kete (2016) adanya SOP dalam pengelolaan ekowisata akan menjadi pedoman bagi wisatawan, pemandu, dan pengelola untuk tetap menjada kualitas lingkungan, meningkatkan kenyamanan, menjadi standardisasi cara menikmati wisata, dan mengurangi tingkat risiko atau bahaya yang mungkin terjadi.

\section{Kesimpulan}

Hasil penelitian dan pembahasan menunjukkan bahwa secara umum 5 prinsip ekowisata berbasis masyarakat telah diupayakan untuk diimplementasikan dalam pengelolaan CMC meskipun kondisi eksisting menunjukkan bahwa masih banyak yang belum optimal. Beberapa kriteria pada masing-masing prinsip ada yang belum dilaksanakan (masih rendah), sedang direncanakan, sedang diupayakan, dan sedang dioptimalkan. Prinsip konservasi alam telah diperhatikan atau menjadi pertimbangan pengelolaan CMC, meskipun pada aspek pengelolaan pengunjung masih sedang (belum optimal). Prinsip konservasi budaya masih kurang dilakukan karena pengelola masih memiliki keterbatasan pengetahuan terkait hal tersebut. Prinsip partisipasi masyarakat belum maksimal meskipun pendirian CMC adalah sepenuhnya prakarsa masyarakat (bukan pemerintah). Aspek membangun hubungan dengan masyarakat, mennjukkan sikap terbuka dan memberikan informasi yang tepat, memaksimalkan dialog, dan kerjasama dengan segenap lapisan masyarakat setempat masih dalam kategori sedang. Prinsip
Ekonomi dalam pengelolaan CMC masih belum maksimal karena belum memberikan kesempatan seluasluasnya kepada masyarakat untuk terlibat sebagai pelaku-pelaku ekonomi kegiatan ekowisata sehingga kesejahteraan belum meningkat secara signifikan. Prinsip edukasi masih lemah meskipun pengelola telah berupaya mengimplementasikan. Kekhasan daerah dan kearifan lokal belum ditonjolkan. Informasi mengenai berbagai hal (keunggulan dan potensi) yang ada di CMC belum dikemas dalam bentuk dan teknik penyampaian yang komunikatif dan inovatif, sehingga selama ini informasi hanya bersifat dari mulut ke mulut. Penerapan prinsip wisata masih belum maksimal, fasilitas penunjang masih sangat terbatas, pelayanan masih lemah, dan SOP pelayanan belum dibuat.

\section{Daftar Pustaka}

[1]. Achmad, A., P.O. Ngakan, A. Umar, Asrianny, 2012. Identifikasi Tutupan Vegetasi dan Potensi Fisik Lahan untuk Pengembangan Ekowisata di Laboratorium Lapangan Konservasi Sumberdaya Hutan dan Ekowisata Hutan Pendidikan UNHAS. Jurnal Penelitian Kehutanan Wallacea. 1(2), pp. 87-102

[2]. Andronicus, F. Yulianda, A. Fahrudin, 2016. Kajian Keberlanjutan Pengelolaan Ekowisata Berbasis Daerah Perlindungan Laut (DPL) di Pesisir Desa Bahoi, Minahasa Utara, Sulawesi Utara. JEMIS. 4(1), pp 1-10.

[3]. Anonim, 2015. Masuk Nominasi Menuju Penghargaan Menuju Indonesia Hijau. [terhubung berkala] http://www.bhaktialam.org/2015/03/masuk-nominasi-menujupenghargaan.html. [30 November 2016].

[4]. Anonim, 2016. Pantai 3 Warna Malang yang Unik dan Sanga Menarik. [terhubung berkala]. https://tempatwisataindonesia.id/pantai-3-warna-malang/ [25 April 2017].

[5]. Anggawa, L.P., 2016. Lia Putrinda Anggawa M-Founder Lembaga Masyarakat Konservasi Bhakti Alam Sendang Biru. [terhubung berkala]. http://putradaerah.com/2016/03/05/314/. [30 November 2016].

[6]. Astra, A.S., E.K. Sabarini, A.M. Harjo, M.B. Maulana, 2014. Keterlibatan Masyarakat dalam Pengelolaan Kawasan Pesisir dan Laut Studi Kasus: Kawasan Perlindungan Pesisir Desa Timbulsloko, Kecamatan Sayung, Kabupaten Demak. Mangrove Capital Project, Bogor.

[7]. CIFOR, 2004. Pembangunan Pariwisata Berbasis Masyarakat. Center for International Forestry Research (CIFOR), Bogor.

[8]. Ditjen PDP-Depbudpar dan WWF Indonesia, 2009. Prinsip dan Kriteria Ekowisata Berbasis Masyarakat. Kerjasama Direktorat Produk Pariwisata Direktorat Jenderal Pengembangan Destinasi Pariwisata Departemen Kebudayaan dan Pariwisata dan WWF Indonesia. Jakarta.

[9]. Ekayani, M., Nuva, Yasmin, R, Shaffitri, L. R., Tampubolon, B. I., 2014a. Taman Nasional Untuk Siapa? Tantangan Membangun Wisata Alam Berbasis Masyarakat di Taman Nasional Gunung Halimun Salak. Risalah Kebijakan Pertanian dan Lingkungan. 1(1), pp. 46-52.

[10]. Ekayani, M., Nuva, R. Yasmin, F. Sinaga, L.O. Maaruf, 2014(b). Wisata Alam Taman Nasional Gunung Halimun Salak: Solusi Kepentingan Ekologi dan Ekonomi. Jurnal Ilmu Pertanian Indonesia. 19(1), pp 29-37.

[11]. El Sahawi, M., 2015. Partisipasi Masyarakat dalam Pengembangan Desa Wisata dan Dampaknya Terhadap Peningkatan Ekonomi Masyarakat. Laporan Studi Pustaka. Departemen Sains Komunikasi Dan Pengembangan Masyarakat, Fakultas Ekologi Manusia, Institut Pertanian Bogor, Bogor.

[12]. Haerani, H.G., 2012. Pengembangan Kawasan Ekowisata di Pulau Maitara Kota Tidore Kepulauan. Jurnal Plano Madani. 1(1), pp 39-46. 
[13]. Hakim, N.S. 2016. Perancangan Web Design Clungup Mangrove Conservation Area Sebagai Media Promosi dan Informasi. Skripsi. Program Studi Desain Komunikasi Visual. Jurusan Seni dan Desain. Fakultas Sastra. Universitas Negeri Malang, Malang.

[14]. Hilman, Y.A., 2016. Kajian Kritis Tentang Inovasi Daerah Terkait Pengembangan dan Pengelolaan Desa Wisata Berbasis Komunitas. Jurnal Ilmiah Pariwisata-STP Trisakti. 21(1), pp 19.

[15]. Huda, I.A.S. dan B.B. Susetyo, 2013. Optimalisasi Pelestarian Ekowisata Mangrove Berbasis Local Wisdomdi Bedul Banyuwangi. Jurusan Pendidikan Geografi, Fakultas Ilmu Sosial, Universitas Negeri Malang, Malang.

[16]. ILO, 2012. Rencana Strategis Pariwisata Berkelanjutan dan Green Jobs untuk Indonesia. Kementerian Pariwisata dan Ekonomi Kreatif Republik Indonesia bekerjasama dengan International Labour Organization (ILO), Jakarta.

[17]. Kete, S.C.R., 2016. Pengelolaan Ekowisata Berbasis Goa: Wisata Alam Goa Pindul. Deepublish, Yogyakarta.

[18]. Koddeng, B., 2011. Zonasi Kawasan Pesisir Pantai Makassar Berbasis Mitigasi Bencana (Studi Kasus Pantai BarambongCelebes Convention Centre). Prosiding Hasil Penelitian Fakultas Teknik.

[19]. Kominfo Jatim, 2016. Mereguk Indahnya Pantai Gatra. [terhubung berkala]. http://kominfo.jatimprov.go.id/read/laporan-utama/meregukindahnya-pantai-gatra [25 April 2017]

[20]. Lasabuda, R., 2013. Pembangunan Wilayah Pesisir Dan Lautan dalam Perspektif Negara Kepulauan Republik Indonesia. Jurnal Ilmiah Platax. 1(2), pp 92-101.

[21]. Meilani, R. dan E.K.S.H. Muntasib, 2013. Peran Kementerian Dalam Negeri Dalam Pengembangan Ekowisata di Indonesia. Media Konservasi. 18(3), pp 135-141.

[22]. Mubariza, R.N., 2015. Promosi Wisata Pantai Clungup Mangrove Conservation Malang Selatan. Tugas Akhir. Program Studi Desain Komunikasi Visual Fakultas Industri Kreatif Universitas Telkom, Bandung

[23]. Mujtaba, A., 2016. Pantai Tiga Warna Malang, Si Pewarnanya Jawa Timur. [terhubung berkala] https://www.wisatawan.id/pantai-tiga-warna-malang.

[24]. Muliya, U., W. Mononimbar, V. Lamahendu, 2016. Kajian Pengembangan Ekowisata Bahari Berbasis Pengelolaan DPL Desa Bahoi di Likupang Barat. Jurnal Spasial. 3(1), pp 75-84.

[25]. Murdiastuti, A., H. Rohman, Suji, 2014. Kebijakan Pengembangan Pariwisata Berbasis Democratic Governance. Pustaka Radja, Surabaya.

[26]. Natural Sunrise Tour, 2015. Wow! Ada Pantai 3 Warna yang Tersembunyi di Malang Selatan. [terhubung berkala]. http://www.naturalsunrisetour.com/wow-ada-pantai-3-warnayang-tersembunyi-di-malang-selatan. [30 November 2016].

[27]. Nugraha, B., I.S. Banuwa, S. Widagdo, 2015. Perencanaan Lanskap Ekowisata Hutan Mangrove di Pantai Sari Ringgung Desa Sidodadi Kecamatan Padang Cermin Kabupaten Pesawaran. Jurnal Sylva Lestari. 3(2), pp 53-66.

[28]. Nugraheni, E., 2002. Sistem Pengelolaan Ekowisata Berbasis Masyarakat di Taman Nasional (Studi Kasus Taman Nasional Gunung Halimun). Tesis. Program Pascasarjana, Institut Pertanian Bogor, Bogor.

[29]. Nurhidayati, S.E. dan C. Fandeli, 2012. Penerapan Prinsip Community Based Tourism (CBT) Dalam PengembanganAgrowisata Di Kota Batu, Jawa Timur. Jejaring Administrasi Publik. 4(1), pp 36-46.
[30]. Nurita, N., Mulatsih, S., Eakayani, M., 2015. Wisata Alam Berbasis Masyarakat Sebagai Upaya Pelestarian Penyu di Pantai Temajuk Kawasan Perbatasan Kalimantan Barat. Risalah Kebijakan Pertanian dan Lingkungan 2(3) pp 151-158.

[31]. Palma, A.S.M., A. Achmad, M. Dasir, 2012. Model Kolaborasi Pengelolaan Taman Nasional Wasur. E-Journal Program Pascasarjana UNHAS. 12(1).

[32]. Pamuji, J., 2015. Inilah Pantai Terbersih yang Ada di Indonesia karena Pengelolaannya. [terhubung berkala]. http://www.kompasiana.com/jihan.pamuji/inilah-pantaiterbersih-yang-ada-di-indonesia-karena-pengelolaannya. [30November2016].

[33]. Priono, Y., 2012. Pengembangan Kawasan Ekowisata Bukit Tangkiling Berbasis Masyarakat. Jurnal Perspektif Arsitektur. 7(1), pp. 51-67.

[34]. Riyadi, D.M.M., 2004. Kebijakan Pembangunan Sumber Daya Pesisir Sebagai Alternatif Pembangunan Indonesia Masa Depan. Disampaikan pada Sosialisasi Nasional Program MFCDP, 22 September.

[35]. Singih, M.N. dan Nirwana, 2016. Perencanaan Dan Pengembangan Desa Wisata Berbasis Masyarakat Dengan Model Partisipatory Rural Appraisal (Studi Perencanaan Desa Wisata Gunungsari, Kecamatan Bumiaji, Kota Batu). Jurnal Pesona. 18(1), pp 1-21.

[36]. Sodikin, 2012. Persepsi Masyarakat Petani Tambak Terhadap Kelestarian Hutan Mangrove di desa Pabean Ilir Kecamatan Pasekan Kabupaten Indramayu. Jurnal GEA. 12(1), pp. 40-48.

[37]. Soedigdo, D. dan Y. Priono, 2013. Peran Ekowisata dalam Konsep Pengembangan Pariwisata Berbasis Masyarakat Pada Taman Wisata Alam (TWA) Bukit Tangkiling Kalimantan Tengah. Jurnal Perspektif Arsitektur. 8(2), pp 1-8

[38]. Soetomo., 2007. Filsafat Pariwisata. Makalah disampaikan pada Pendidikan dan Pelatihan Peningkatan Mutu Tenaga Kepariwisataan 22-26 Mei 2007, STIEPARI, Semarang.

[39]. Subekti, S., 2012. Pengelolaan Mangrove Sebagai Salah Satu Keanekaragaman Bahan Pangan. Prosiding SNST ke-3 Tahun 2012 Fakultas Teknik Universitas Wahid Hasyim Semarang.

[40]. Sumaraw, C.A., L. Tondobala, V. Lahamendu, 2016. Analisis Kesesuaian Lahan Untuk Pengembangan Ekowisata di Sekitar Danau Tondano. Jurnal Spasial. 3(1), pp 95-105.

[41]. Tambunan, R., R.H. Harahap, Z. Lubis, 2005. Pengelolaan Hutan Mangrove di Kabupaten Asahan (Studi Kasus Partisipasi Masyarakat dalam Pengelolaaan Hutan Mangrove di Kecamatan Lima Puluh Kabupaten Asahan). Jurnal Studi Pembangunan. 2, pp. 55-69.

[42]. TIES, 2016. What is Ecotourism? The International Ecotourism Society. [terhubung berkala]. https://www.ecotourism.org/ [25 April 2017].

[43]. Vibriyanto, N., A. Ismail, M. Ekayani, 2015. Manfaat Ekonomi dan Daya Dukung Kawasan Pantai Lombang Kabupaten Sumenep Puopinsi Jawa Timur. Risalah Kebijakan Pertanian dan Lingkungan. 2(2), pp 152-159.

[44]. Wisata Pulau Jawa, 2016. Clungup Mangrove Conservation. [terhubung berkala]. http://www.tourdejava.net. [30 November 2016].

[45]. Yulius, dan Arifin, T., 2014. Analisis Sistem Informasi Geografis (SIG) untuk Potensi Wisata Pantai di Kota Makassar, Provinsi Sulawesi Selatan. Tata Loka. 16(3), pp 145-152. 